\title{
Abdominal and pelvic ultrasound study of the maned wolf (Chrysocyon brachyurus) $^{1}$
}

\author{
Luciana D. Guimarães ${ }^{2 *}$, Maria Cristina F.N.S. Hage ${ }^{3}$, Tarcízio A.R. Paula ${ }^{2}$, Andréa \\ P.B. Borges ${ }^{2}$, Moacir Carretta Júnior ${ }^{2}$, Ayisa R. Oliveira ${ }^{2}$, Filipe T. Carneiro ${ }^{2}$ \\ and Vinicius H.D. Silva ${ }^{2}$
}

\begin{abstract}
Guimarães L.D., Hage M.C.F.N.S., Paula T.A.R., Borges A.P.B., Carreta Jr M., Rodrigues A., Carneiro F.T. \& Silva V.H.D. 2013. Abdominal and pelvic ultrasonographic study of the maned wolf (Chrysocyon brachyurus). Pesquisa Veterinária Brasileira 33(2):265272. Departamento de Veterinária, Centro de Ciências Biológicas e da Saúde, Universidade Federal de Viçosa, Avenida Peter Henry Rolfs s/n, Viçosa, MG 36570-000, Brazil. E-mail: ludiegues@yahoo.com.br

The aim of the present study was the ultrasound characterization of the abdominal and pelvic regions of five maned wolves kept in captivity at the Triage Center of Wild Animals of the Federal University of Viçosa (Centro de Triagem de Animais Silvestres, Universidade Federal de Viçosa). This characterization included descriptions of ultrasonographic aspects and measurements of various structures using B-mode ultrasound. Biometric data were collected to assess the existence of significant linear correlations between these measurements and the measurements obtained by ultrasound. Additionally, hematological and serum biochemistry evaluations of the animals were performed. The ultrasound findings were similar to those available in the literature on domestic dogs, which were used for comparison as a result of the lack of published data regarding maned wolves. The latter species showed characteristics closely resembling those of the former, differing in the spleen and left renal cortex echogenicities, in the appearance of the prostatic and testicular regions and in the hepatic portal vein morphology. In the current study, the biometric values were similar to those previously published; however, no data regarding thoracic perimeter, modified crown-rump length or thoracic depth were found in the literature for this Canidae species. Statistical analysis showed the existence of a strong negative correlation between the modified crown-rump length and left renal length, between the modified crown-rump length and the right renal volume, between the thoracic perimeter and the height at the cranial pole of the left adrenal gland and between the thoracic perimeter and the height at the caudal pole of the left adrenal gland. Laboratory findings, including segmented neutrophil, eosinophil, monocyte and lymphocyte counts and the serum levels of glucose, ALT, alkaline phosphatase, urea, total protein, globulin, creatine phosphokinase, triglyceride, sodium, phosphate, potassium and chloride, were inconsistent with values found by other authors. The ultrasound is a diagnostic imaging method that must be further explored in the medicine of wild animals; therefore, additional research in this area is required.
\end{abstract}

INDEX TERMS: Maned wolf, abdominal ultrasound, pelvic ultrasound, biometrics.

\footnotetext{
${ }^{1}$ Received on October 30, 2012.

Accepted for publication on January 23, 2013.

${ }^{2}$ Departamento de Veterinária, Centro de Ciências Biológicas e da Saúde (CCB), Universidade Federal de Viçosa (UFV), Avenida P. H. Rolfs s/n, Viçosa, MG 36570-000, Brasil. *Corresponding author: ludiegues@yahoo.com.br

${ }^{3}$ Departamento de Medicina Veterinária, Faculdade de Zootecnia e Engenharia de Alimentos (FZEA), Av. Duque de Caxias Norte 225, Campus da Universidade de São Paulo (USP), Pirassununga, SP 13635-900, Brazil. Bolsista de produtividade CNPq.
}

RESUMO.- [Estudo ultrassonográfico abdominal e pélvico de lobo-guará (Chrysocyon brachyurus).] 0 presente trabalho objetivou a caracterização ultrassonográfica das regiões abdominal e pélvica de cinco lobos-guarás mantidos em cativeiro no Centro de Triagem de Animais Silvestres da Universidade Federal de Viçosa, com descrição dos aspectos ultrassonográficos e obtenção de medidas de suas diversas estruturas, por meio de ultrassonografia modo-B. 
Coletaram-se dados de biometria corporal com a finalidade de se verificar a existência de correlação linear significativa entre estas medidas e as mensurações obtidas ultrassonograficamente. Adicionalmente, efetuou-se avaliação hematológica e bioquímica sérica dos animais. Os achados ultrassonográficos foram equiparados aos existentes na literatura de cães domésticos devido à inexistência de dados publicados referentes a lobos-guarás. Esta espécie apresentou características muito semelhantes às do cão, diferindo nas ecogenicidades do baço e córtex renal esquerdo, no aspecto da região prostática, testicular e na morfologia da veia porta hepática. No presente estudo, os valores de biometria corporal foram semelhantes aos anteriormente publicados, porém não se encontraram dados na literatura referentes a perímetro torácico, comprimento vértice-caudal modificado e profundidade torácica para esta espécie de canídeo. A análise estatística revelou a existência de forte correlação negativa entre o comprimento vértice caudal modificado e o comprimento renal esquerdo, entre o comprimento vértice caudal modificado e o volume renal direito, entre o perímetro torácico e a altura do polo cranial da glândula adrenal esquerda e entre o perímetro torácico e a altura do polo caudal da glândula adrenal esquerda. Laboratorialmente, a contagem de neutrófilos segmentados, eosinófilos, monócitos e linfócitos e os níveis séricos de glicose, ALT, fosfatase alcalina, ureia, proteína total, globulina, creatina fosfoquinase, triglicérides, sódio, fosfato, potássio e cloreto foram discordantes de valores obtidos por outros autores. A ultrassonografia é um método de diagnóstico por imagem que necessita ser mais explorado na medicina de animais silvestres, sendo, portanto necessário o incremento de pesquisas nesta área.

TERMOS DE INDEXAÇÃO: Lobo-guará, ultrassonografia abdominal, ultrassonografia pélvica, biometria corporal.

\section{INTRODUCTION}

The maned wolf is the largest canid of South America (Dietz 1985). Although this canid inhabits large areas, it is classified as "vulnerable" according to the Brazilian fauna national species list of animals threatened with extinction (IBAMA 2003); in spite of this fact, these wolves are commonly found in Brazilian zoos (Maia \& Gouveia 2002).

Ultrasound examination is a noninvasive, low-cost, and underutilized diagnostic method in the veterinary medicine of wild animals; it is the best way to characterize the abdominal and pelvic organs, thereby enabling the evaluation of echogenicity, echotexture, positioning, and structural dimensions. Little is known with regard to the abdomen and pelvis ultrasound examination of maned wolves; as a whole, the literature concerning diagnostic imaging is rare in this species. Ultrasound knowledge of these regions assists in the diagnosis of abdominal and pelvic disorders that are common to maned wolves, including dioctophymosis, pyometra, kidney stones, and urinary tract infections.

In the current study were performed abdominal and pelvic-region ultrasounds of five maned wolves kept in captivity at the Wild Animal Triage Center of the Federal University of Viçosa (Centro de Triagem de Animais Silvestres,
Universidade Federal de Viçosa; CETAS/UFV) in Viçosa, Minas Gerais. Its overall goals consisted of describing the abdominal and pelvic-region anatomies of this wild canid via ultrasound, biometric data collection (i.e., tail length, modified crown-rump length, snout-rump length, thoracic perimeter, and thoracic depth) and laboratory testing (i.e., renal, hepatic, and pancreatic profiles, complete blood counts, and serum doses of glucose, creatine kinase, total protein, bilirubin, and electrolytes). In addition, this study compared the obtained biometric data and laboratory values with the specialized literature. Specifically, this study included ultrasound characterizations of the positioning, dimensions, echogenicity, and echotexture of each abdominal and pelvic organ and compared these results with those available in the literature concerning domestic dogs to emphasize the differences between these species.

\section{MATERIALS AND METHODS}

Five maned wolves ( 3 males and 2 females) kept in captivity at the Wild Animal Triage Center of the Federal University of Viçosa (Centro de Triagem de Animais Silvestres, Universidade Federal de Viçosa; CETAS/UFV) were studied. The animals were numbered from 1 to 5 based on their chronological order of assessment. Inclusion and exclusion criteria did not exist because these are rare specimens of Brazilian fauna, and all of the animals available for the study were included. Biometric measurements were taken, and the animals were submitted to pelvic and abdominal ultrasounds as well as laboratory evaluations. The Animal Ethics Committee of the Federal University of Viçosa (Comissão de Ética para Uso de Animais, Universidade Federal de Viçosa; CEUA/UFV) and the Brazilian Institute of the Environment and Renewable Natural Resources (Instituto Brasileiro do Meio Ambiente e dos Recursos Naturais Renováveis; IBAMA) approved this project.

After a previous period of fasting, the animals were manually restrained and chemical restraint was performed using $1.0 \mathrm{mg} / \mathrm{kg}$ xylazine and $8.0 \mathrm{mg} / \mathrm{kg}$ ketamine administered intramuscularly as recommended by Pessuti \& Santiago (1994). The anesthesia was maintained intravenously by administering propofol in 5-mg boluses at approximately 3-minute intervals. The vital signs of the wolves were continuously monitored.

The following biometric measurements were assessed: snout-rump length (from the apex of the snout to the base of the tail), modified crown-rump length (from the occipital crest to the base of the tail along the spine), thoracic perimeter (chest circumference measured immediately caudal to the thoracic limbs), thoracic depth (from the xiphoid process to the most dorsal portion of the thoracic spine), and tail length (from its base to the end of the last coccygeal vertebra).

A portable ultrasound device (SonoSite 180 Plus) equipped with a sector transducer (4.0- to 7.0-MHz broadband) and an electronic linear transducer (5.0- to $10.0-\mathrm{MHz}$ broadband) was used for the examination. The evaluation applied the following scanning sequence. The examination of the left inguinal region was initiated with the animal in the right lateral decubitus to assess the bladder. Next, the prostatic and testicular regions of males and the uterine region (when able to be visualized) in females were evaluated. The caudal vena cava, the abdominal aortic artery and its trifurcation, and the left and right iliac arteries were visualized cranially to the bladder through a left lateral access. The left renal artery, the left ovary (in females), and the left kidney and right adrenal gland were examined cranially. The spleen and the stomach were evaluated by scanning the left and ventral epigastric regions. The liver was visualized by moving the transducer 
along the length of the last pair of ribs and the last intercostal spaces while the animal was in the left lateral decubitus position. The aorta, the caudal vena cava, and the hepatic portal vein were also examined by medially angling the transducer. Finally, the right kidney, the right renal artery, the right ovary (in females), the right adrenal gland, and the intestinal loops were examined. The pancreas and lymph nodes were also evaluated when visible.

Blood samples were collected via cephalic or lateral saphenous vein punctures and processed at the Veterinary Department Clinical Laboratory of the Federal University of Viçosa (Laboratório Clínico do Departamento de Veterinária, Universidade Federal de Viçosa). The lab performed complete blood counts and measured serum levels of urea, creatinine, alanine aminotransferase (ALT), aspartate transferase (AST), gamma glutamyl transferase (GGT), alkaline phosphatase (ALP), creatine kinase (CK), amylase, lipase, glucose, total protein and fractions, calcium, phosphate, magnesium, sodium, potassium, chloride and total, direct, and indirect bilirubin.

\section{RESULTS AND DISCUSSION}

\section{Biometric data}

The age of the maned wolves ranged from 1 to 6 years, and their body weight ranged from $19.3 \mathrm{~kg}$ to $28.0 \mathrm{~kg}$ (mean=23.6 $\mathrm{kg}$ ). The biometric values are found in Table 1. Only the values for body weight, total body length (snout-rump), and tail length were found in the literature. The current study also recorded the modified crown-rump length, thoracic depth, thoracic perimeter, and tail length. The mean values found in the current study and the literature are shown in Table 2 . The mean body weight of the animals approximated the averages found by the authors cited. Fletchall (1995) also emphasizes that animals in captivity can reach up to $30.0 \mathrm{~kg}$ in body weight. The snout-rump and tail lengths were similar to those described by at least one of the authors cited.

\section{Ultrasound evaluation}

The ultrasound findings were compared with those in the literature for the domestic dog (Canis familiaris) due to the lack of reports that describe the ultrasound appearan-

Table 1. Biometric values of the maned wolves

\begin{tabular}{ccccccc}
\hline & A1 & A2 & A3 & A4 & A5 & Média \\
\hline SR $(\mathrm{cm})$ & 108.00 & 110.00 & 105.00 & 113.00 & 108.00 & $108.80 \pm 2.94$ \\
CRm $(\mathrm{cm})$ & 79.00 & 84.00 & 84.00 & 83.00 & 84.00 & $82.80 \pm 2.16$ \\
TPe $(\mathrm{cm})$ & 61.00 & 64.00 & 57.00 & 58.00 & 59.00 & $59.80 \pm 2.77$ \\
TDe $(\mathrm{cm})$ & 31.00 & 32.00 & 28.00 & 31.00 & 31.00 & $30.60 \pm 1.51$ \\
Tail $(\mathrm{cm})$ & 45.00 & 46.00 & 45.00 & 48.00 & 43.00 & $45.40 \pm 1.81$
\end{tabular}

$\overline{\mathrm{A} 1}=$ animal $1 ; \mathrm{A} 2=\operatorname{animal} 2 ; \mathrm{A} 3=$ animal $3 ; \mathrm{A} 4=$ animal $4 ; \mathrm{A} 5=$ animal 5; $\mathrm{SR}=$ snout-rump length; $\mathrm{CRm}=$ modified crown-rump length; $\mathrm{TPe}=$ thoracic perimeter; TDe $=$ thoracic depth.

Table 2. Mean maned wolf biometric data assessed in this study as well as in Dietz (1984), Fletchall (1995) and Ramos Jr et al. (2003)

\begin{tabular}{|c|c|c|c|c|}
\hline & This study & $\begin{array}{c}\text { Dietz } \\
(1984)\end{array}$ & $\begin{array}{c}\text { Fletchall } \\
\text { (1995) }\end{array}$ & $\begin{array}{c}\text { Ramos Jr. } \\
\text { et al. (2003) }\end{array}$ \\
\hline Body weight (kg) & $\begin{array}{c}23.60 \\
(19.30-28.0) \\
108.8\end{array}$ & 23.30 & $\begin{array}{c}\text { 20.00-23.00; } \\
\text { in captivity: } \\
30.00\end{array}$ & $20.00-23.00$ \\
\hline Snout-rump length $(\mathrm{cm})$ & $\begin{array}{l}(105.00- \\
113.00)\end{array}$ & 103.00 & $\begin{array}{c}100.00-125.00 \\
45.40\end{array}$ & $124.50-132.00$ \\
\hline Tail length $(\mathrm{cm})$ & $(43.00-48.00)$ & 44.50 & $30.00-45.00$ & $28.00-40.50$ \\
\hline
\end{tabular}

ce and dimensions of the abdominal and pelvic organs in Chrysocyon brachyurus.

The bladder was visualized as a slightly to moderately filled globular structure located in the caudal abdominal region ventral to the descending colon. The wall layers were distinguished in the wolves as related in dogs for Finn-Bodner (1995). This author describes the ultrasound appearance of the bladder wall as two thin hyperechogenic lines (which correspond to the serosa and submucosal layers) separated by a thin hypoechogenic line (which corresponds to the triple muscle layer). In maned wolves, the bladder filling was small to moderate, and the bladder-wall thickness ranged from $0.17 \mathrm{~cm}$ to $0.28 \mathrm{~cm}$, with a mean thickness of $0.25 \mathrm{~cm}$. In dogs, this value ranges from $0.14 \mathrm{~cm}$ to $0.23 \mathrm{~cm}$ depending on, and a $0.01-\mathrm{cm}$ increase can occur in larger breed animals (Geisse et al. 1997).

In the renal evaluation, the renal medulla was the least echogenic renal structure visualized in the maned wolves followed by the renal cortex; this finding was consistent with observations in dogs by Nyland et al. (2004a), Kealy \& McAllister (2005) and D'Anjou (2008a). In addition, these authors found that renal cortex echogenicity was lower than or equal to hepatic echogenicity and far below splenic echogenicity. In the current renal evaluation, isoechogenicity was noted between the right renal cortex and the liver in all animals. Furthermore, the spleen and the left renal cortex showed similar echogenicity in $60 \%$ of the cases, which contrasts with the results found in dogs (Fig.1). The remaining $40 \%$ of the cases presented a left renal cortex echogenicity that was slightly below the splenic echogenicity and not far below the splenic echogenicity as described in dogs. The renal echotexture was similar across species, and Vac (2004) described it as finely granular in dogs. The comparisons of echogenicities between the right kidney and the liver as well as between the left kidney and spleen were performed using the same image depth and equipment settings. Renal dimensions vary greatly in dogs due to differences between breeds; the length can range from $3 \mathrm{~cm}$ to $10 \mathrm{~cm}$, and the thickness of the cortical region can vary

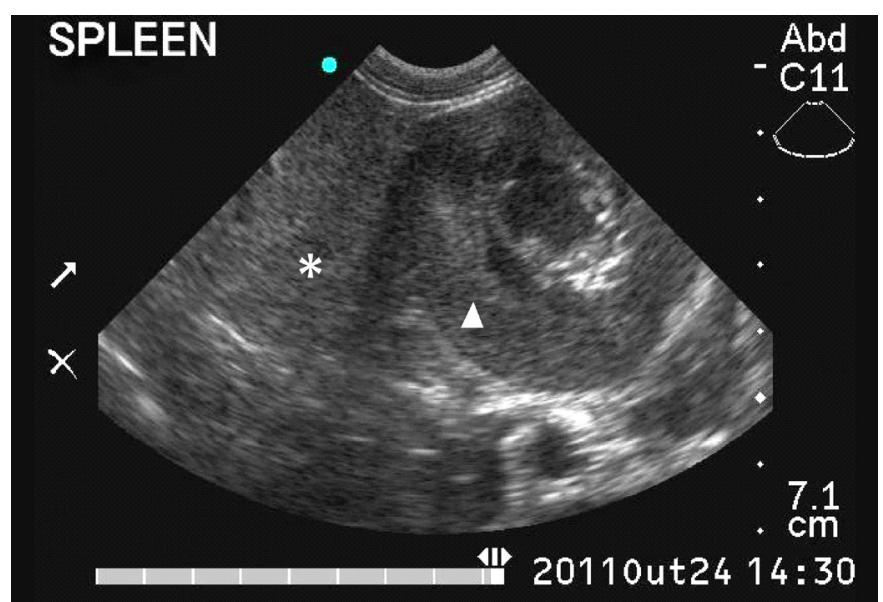

Fig.1. Ultrasound image of a maned wolf spleen (asterisk) and left kidney (arrowhead), which reveals the isoechogenicity that exists between the splenic parenchyma and that of the renal cortical region. 
from $0.3 \mathrm{~cm}$ to $0.8 \mathrm{~cm}$ (Larson 2009). Wolf kidneys ranged in length from $6.33 \mathrm{~cm}$ to $8.0 \mathrm{~cm}$, and the cortical thickness ranged from $0.71 \mathrm{~cm}$ to $1.35 \mathrm{~cm}$; the cortical region dimensions were higher in wolves than in dogs.

The structures visualized in the topography of the prostate were inconspicuous for all males; the echogenicity was similar to that of the surrounding tissue. In dogs, the prostate is a well-developed gland that can be hyperechoic or hypoechoic relative to the surrounding tissue. Moreover, its dimensions vary with age and depend on whether the animal is castrated (Mattoon \& Nyland 2004). Therefore, the ultrasound characteristics of the prostatic region significantly differed between dogs and wolves. We suggest conducting anatomopathological studies to macroscopically identify the prostate of the maned wolf that died naturally.

The ultrasound appearance of the wolves' testicles differed from that of dogs. According to Mattoon and Nyland (2004), canine testicles are echogenic with a homogeneous echotexture; moreover, the mediastinum is echogenic and clear, whereas the testicles of wolves were hypoechoic with a coarse echotexture, and the mediastinum was slightly echogenic and poorly defined (Fig.2). According to Christensen (1964), the testes of approximately $11.3 \mathrm{~kg}$ dogs had $2.8 \mathrm{~cm}$ to $3.1 \mathrm{~cm}$ of length and $2.0 \mathrm{~cm}$ to $2.2 \mathrm{~cm}$ in thickness. Santos et al. (2004) found that the testes of adult German Shepherd dogs had $4.29 \mathrm{~cm}$ of length and $2.74 \mathrm{~cm}$ in thickness on average. In the present study, the testicles of maned wolves had $2.87 \mathrm{~cm}$ of length and $1.22 \mathrm{~cm}$ in thickness on average. Because dogs have significant variations in testicular dimensions due to the large variation among breeds and body weights that exist, some disparity was expected with regard to the comparison of testicular measurements of dogs and maned wolves.

The uterus was not visualized in any females evaluated; similarly, Hecht (2008a) stated that the uteruses of non-pregnant bitches are difficult to observe via ultrasound.

The left and right ovaries of females were $1.02 \mathrm{~cm}$ length by $0.67 \mathrm{~cm}$ width and $1.23 \mathrm{~cm}$ length by $0.81 \mathrm{~cm}$ width on average, respectively. According to Hecht (2008a), the ovaries of bitches have approximately $2 \mathrm{~cm}$ in length and can measure up $1.2 \mathrm{~cm}$ during anestrus; during proestrus, follicles resemble cystic structures that vary in number and are associated with ovarian parenchyma. In the current study, one of the females showed an anechogenic and rounded structure of $1.12 \mathrm{~cm}$ length by $0.32 \mathrm{~cm}$ width that was associated with the left ovarian parenchyma and appeared similar to a cyst (Fig.3). This found is consistent with the ultrasound description of the ovarian follicles of bitches.

The spleen was visualized in the left epigastric and left mesogastric regions in the maned wolves. It had a regular and echogenic capsule surrounding a finely granular, homogeneous parenchyma, which was hyperechoic when compared to the liver. These characteristics are similar to those reported by Hecht (2008b) in dogs, except with regard to the echogenicity in the renal cortex. As previously stated, the splenic echogenicity resembled that of the left kidney cortical region in most wolves, which demonstrates a unique feature of these canids.

The echotexture and echogenicity of the liver parenchy-

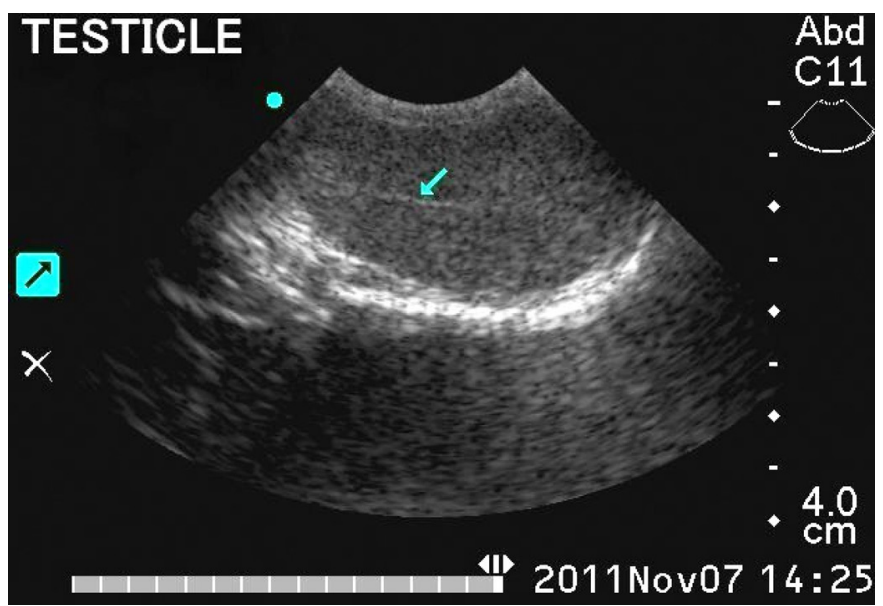

Fig.2. Ultrasound image of a maned wolf testicle in the sagittal plane. Note the coarse echotexture and the vague definition of the mediastinal line (arrow).

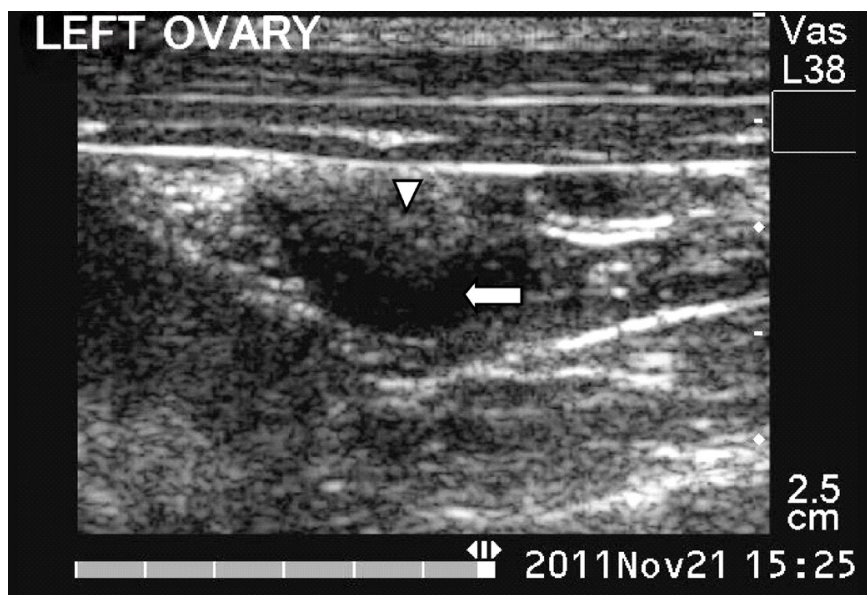

Fig.3. Ultrasound image of a maned wolf ovary in the sagittal plane. Note the hypoechoic area (arrowhead) that corresponds to the ovarian parenchyma and the anechogenic region (arrow), which is consistent with the ovarian follicle ultrasound image.

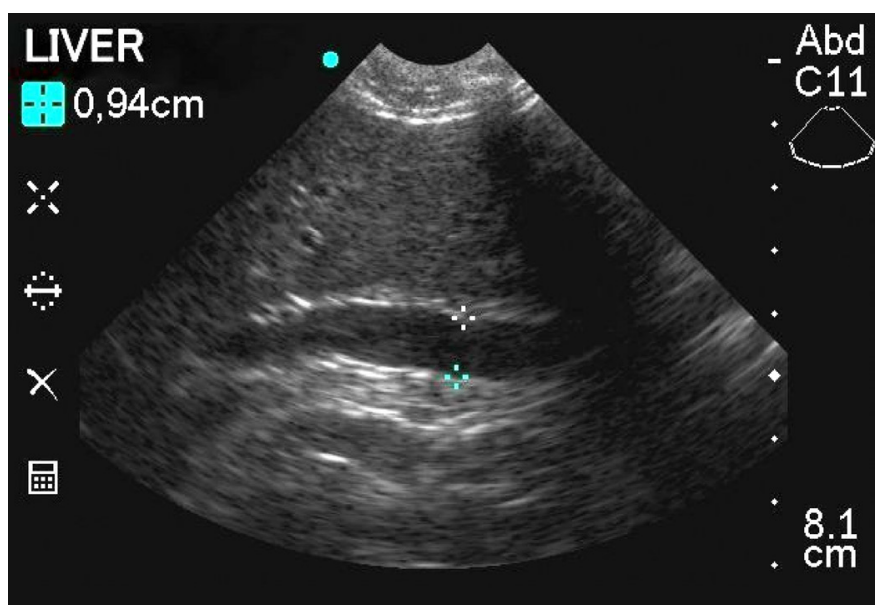

Fig.4. Ultrasound image of a maned wolf liver, which shows the hepatic portal vein in the sagittal plane, delimited by calipers. Note the marked sigmoid morphology. A region with the formation of acoustic shadowing due to the presence of a rib is noted to the right of the image. 
ma of maned wolves were similar to those of dogs. Moreover, the hepatic echotexture was somewhat coarser than the splenic parenchyma, and the liver parenchymal echogenicity was similar to that of the right renal cortex. Furthermore, identifying the liver lobes is impossible in both species under normal situations (Nyland et al. 2004b, Kealy \& McAllister 2005, D'Anjou 2008b). The hepatic portal vein had a well-marked sigmoid shape in all maned wolves (Figure 4); this vessel and the diaphragmatic segments of the caudal vena cava and aorta were measured (Table 3 ). The values obtained were lower than those found by Sartor (2008) in dogs with body weights similar to those of the wolves evaluated.

The gallbladder was moderately full in all animals, with a thin wall and anechogenic content with clear posterior acoustic enhancement. There were no differences in regards the sonographic features described for dogs. The

Table 3. Measurement of the hepatic blood vessels and the major abdominal vessels of the maned wolves in the sagittal plane

\begin{tabular}{|c|c|c|c|c|c|c|}
\hline & $\mathrm{A} 1$ & A2 & $\mathrm{A} 3$ & A4 & A5 & Média \\
\hline Hepat & 0.84 & 94 & 0.55 & 5 & 0.62 & \\
\hline $\begin{array}{l}\text { Caudal } \\
\text { mati }\end{array}$ & & .59 & 0.41 & & .62 & \\
\hline $\begin{array}{r}\text { Aorta } \\
\text { segm }\end{array}$ & 92 & & 0.75 & 0.75 & 0.75 & $0.79 \pm 0.07$ \\
\hline $\begin{array}{r}\text { Caudal } \\
\text { abdor }\end{array}$ & 70 & 1.22 & 0.79 & 0.68 & 0.57 & $0.81 \pm 0.24$ \\
\hline Aorta & 0.80 & & & 0.66 & 66 & \\
\hline & - & 0.36 & 0.45 & 0.40 & 0.40 & $0.40 \pm 0.03$ \\
\hline Aort & 0.43 & 0.31 & 0.38 & 0.23 & 0.37 & $0.34 \pm 0.15$ \\
\hline Right external iliac artery $(\mathrm{cm})$ & 0.54 & & 0.27 & 0.31 & 0.44 & $0.39 \pm 0.10$ \\
\hline
\end{tabular}

$\mathrm{A} 1=\operatorname{animal} 1 ; \mathrm{A} 2=\operatorname{animal} 2 ; \mathrm{A} 3=\operatorname{animal} 3 ; \mathrm{A} 4=\operatorname{animal} 4 ; \mathrm{A} 5=$ animal 5. Dashes denote missing data.

dimensions of the caudal vena cava and aorta cranially to the aortic trifurcation as well as the dimensions of the left and right external iliac arteries were assessed in a sagittal section. The extent of aorta branching in the segment caudal to its trifurcation was also measured. As in dogs, the major abdominal vessels were readily visualized in all wolves. The dimensions of the aorta cranially to its trifurcation as well as the left and right external iliac arteries reached mean values close to those reported for dogs by Kamikawa and Bombonato (2007), as shown in Table 4.

The stomach was identified in the cranial portion of the abdomen caudal to the liver. It was found without food contents or much gas. The animal 4 was diagnosed with a congenital esophageal hiatal hernia of intermittent nature at 6 months old (see Peixoto et al. 2009). Anatomical or morphological changes were not found in the stomach of that animal according to the ultrasound assessment. The intestinal loops lacked food contents and showed even distributions throughout the abdominal cavity in all animals. The ultrasound appearance of the gastrointestinal tract components of maned wolves was consistent with the description for dogs according to Penninck (2008); it was possible to identify the interface between the lumen and the mucosal surface as well as the layers of the gastric and intestinal
Table 4. The mean values of the aortic artery segment in a cranial position to its trifurcation as well as the left and right external iliac arteries mean values in the sagittal section compared with those obtained by Kamikawa \& Bombonato (2007) using cross sections

\begin{tabular}{lcc}
\hline & $\begin{array}{c}\text { Maned } \\
\text { wolves }\end{array}$ & $\begin{array}{c}\text { Dogs (Kamikawa } \\
\text { \& Bombonato 2007) }\end{array}$ \\
\hline Aorta (cranial to trifurcation) & $0.73 \mathrm{~cm}$ & $0.69 \mathrm{~cm}$ \\
Left external iliac artery & $0.40 \mathrm{~cm}$ & $0.39 \mathrm{~cm}$ \\
Right external iliac artery & $0.39 \mathrm{~cm}$ & $0.42 \mathrm{~cm}$ \\
Caudal vena cava & $0.81 \mathrm{~cm}$ & - \\
\hline
\end{tabular}

Dashes denote missing data.

walls (mucosa, submucosa, muscle, and serosa), and measure their thickness, in both species. The wolves' mean gastric wall thickness was $0.52 \mathrm{~cm}$, whereas it ranges from $0.3 \mathrm{~cm}$ to $0.5 \mathrm{~cm}$ in dogs according to Penninck (2004). In addition, the wall thickness of the loops ranged from $0.2 \mathrm{~cm}$ to $0.3 \mathrm{~cm}$ in dogs according to Penninck et al. (1989), whereas the walls of the intestinal loops ranged from $0.37 \mathrm{~cm}$ to $0.51 \mathrm{~cm}$, with a mean value of $0.44 \mathrm{~cm}$, in the maned wolves of the current assessment.

An elongated hypoechoic structure located in the dorsal region of the duodenum that was consistent with the topography and parenchyma of the pancreas was noted in only one animal. This organ is also seldom visualized using ultrasound evaluation in dogs (Nyland et al. 2004c).

The adrenal glands were identified by scanning a region craniomedial to the kidneys and were more easily visualized by following the trajectory of the phrenicoabdominal artery along these glands using the Doppler mode. The lengths and heights of the cranial and caudal poles are found in Table 5. As Graham (2008) found in dogs, the adrenal glands of maned wolves were also well-defined structures that have an elongated shape resembling a peanut, with echogenicity lower than that of the adjacent fat. In dogs, the width and thickness of each gland should not exceed $0.74 \mathrm{~cm}$ unless enlarged (Barthez et al. 1995). The dimensions of the evaluated animals' adrenal glands were similar to those found in domestic dogs.

The lymph nodes found were hypoechoic and had an elongated shape in all animals, as D'Anjou (2008c) noted in dogs. The mesenteric lymph nodes were the most frequently visualized nodes and were identified in three of the five animals examined. D'Anjou (2008c) also reported that the lymph nodes most commonly identified using ultrasound

Table 5. Dimensions of the adrenal glands of maned wolves

\begin{tabular}{llcccccc}
\hline Gland & \multicolumn{1}{c}{ Parameters } & A1 & A2 & A3 & A4 & A5 & Mean \\
\hline $\begin{array}{l}\text { Left } \\
\text { adrenal }\end{array}$ & Length $(\mathrm{cm})$ & 1.80 & - & 1.50 & 1.30 & 1.98 & $1.64 \pm 0.30$ \\
& $\begin{array}{l}\text { Height at the cranial } \\
\text { pole }(\mathrm{cm})\end{array}$ & 0.46 & 0.59 & 0.58 & 0.52 & 0.49 & $0.52 \pm 0.05$ \\
& $\begin{array}{l}\text { Height at the caudal } \\
\text { pole }(\mathrm{cm})\end{array}$ & 0.29 & - & 0.45 & 0.41 & 0.33 & $0.37 \pm 0.07$ \\
Right & $\begin{array}{l}\text { Length (cm) } \\
\text { adrenal }\end{array}$ & - & 2.03 & 2.23 & 0.99 & 1.48 & $1.68 \pm 0.56$ \\
& $\begin{array}{l}\text { Height at the cranial } \\
\text { pole }(\mathrm{cm})\end{array}$ & - & 0.36 & 0.43 & 0.40 & 0.31 & $0.37 \pm 0.05$ \\
& $\begin{array}{l}\text { Height at the caudal } \\
\text { pole (cm) }\end{array}$ & - & 0.60 & 0.52 & 0.22 & 0.42 & $0.44 \pm 0.16$ \\
& & & & & &
\end{tabular}

$\overline{\mathrm{A} 1}=$ animal 1; $\mathrm{A} 2=\operatorname{animal} 2 ; \mathrm{A} 3=\operatorname{anim} a l 3 ; \mathrm{A} 4=\operatorname{animal} 4 ; \mathrm{A} 5=$ animal 5. Dashes denote missing data. 
are mesenteric (or jejunal). Furthermore, the ultrasound features of the external iliac arteries are similar among wild and domestic canids.

\section{Data analyses}

The only significant Pearson's linear correlations found $(\alpha=0.05)$ were those between the modified crown-rump length and the left kidney length $(r=-0.937)$, between the modified crown-rump length and the right kidney volume $(r=-0.910)$, between the thoracic perimeter and the height of the left adrenal gland at the cranial pole ( $\mathrm{r}=-0.943)$, and between the thoracic perimeter and the height of the right adrenal gland at the cranial pole $(\mathrm{r}=-0.962)$. According to the classification proposed by Callegari-Jacques (2003), these correlations are strong. Furthermore, they are negative; that is, as the value of one variable increases, the value of the other variable decreases and vice-versa.

\section{Laboratory evaluation}

The reference values for hematological and serum biochemical parameters reported in the literature for Chrysocyon brachyurus vary considerably across studies. The data acquired in the current study were compared with those published by Dietz (1984), Barbiers \& Bush (1995), Mattos (2003), and May-Júnior et al. (2009) (Tables 6 and 7). Taking the values reported in the literature as references, the absolute and percentage mean values of eosinophils and monocytes in the blood cell count were higher than expected. Similarly, the absolute and percentage mean values of segmented neutrophils and the absolute mean count of lymphocytes were lower than the reference values. The blood serum evaluation revealed increases in the mean values of glucose, ALT, and alkaline phosphatase as well as decreases in the mean levels of urea, total protein, globulin, creatine phosphokinase, triglycerides, sodium, phosphate, potassium, and chloride. Although many of these tests had below or above average results, they were within range of the variations reported by May-Júnior et al. (2009). According to Couto (2001), eosinophilia often results from parasitic diseases in dogs, especially roundworm and hookworm infestations, which might analogously explain the eosinophilia found among maned wolves. Monocytosis and lymphopenia have been noted in the stress leukograms of dogs (Couto 2001). The maned wolves evaluated in this study are predisposed to stress because they are in captivity; in addition, this stress is compounded by the physical and chemical restraint applied in this study; thus, the decrease in lymphocytes and the increase in monocytes might have resulted from these conditions. However, other factors must be considered. Dietz (1984), Mattos (2003), and May-Júnior et al. (2009) studied free-living wild animals, and the differences between wild and captive animals with regard to diet, habits, and stress might lead to the results obtained. The number of animals evaluated in each study should also be considered. Dietz (1984) studied eight animals; however, Barbiers \& Bush (1995) conducted a broader evaluation by studying approximately 130 animals using a hematological evaluation and a variable number of wolves (1-82 animals) in a serum/biochemical evaluation. Both Mattos (2003) and May-Júnior et al. (2009) used 28 animals in their researches. The small number of wolves included in the current study limits the standardization of the values obtained with regard to blood assessments, biometrics, and ultrasound evaluations. Therefore, these data

Table 6. The mean hematological values of the maned wolves in the current study compared with those of Dietz (1984), Barbiers \& Bush (1995), Mattos (2003) and May-Júnior et al. (2009)

\begin{tabular}{lccccc}
\hline & This study & $\begin{array}{c}\text { Dietz } \\
(1984)\end{array}$ & $\begin{array}{c}\text { Barbiers \& } \\
\text { Bush }(1995)\end{array}$ & $\begin{array}{c}\text { Mattos } \\
(2003)\end{array}$ & $\begin{array}{c}\text { May-Júnior } \\
\text { et al. (2009) }\end{array}$ \\
\hline Erythrocytes $\left(10^{6} / \mathrm{mm}^{3}\right)$ & $5.44 \pm 0.61$ & $6.3 \pm 1.00$ & $5.40 \pm 4.62$ & $6.40 \pm 1.90$ & $5.00 \pm 0.10$ \\
Hemoglobin (g/dL) & $14.02 \pm 1.26$ & $12.2 \pm 1.72$ & $14.60 \pm 2.60$ & $11.60 \pm 2.50$ & $13.10 \pm 0.30$ \\
Hematocrit (\%) & $40.70 \pm 5.09$ & $38.1 \pm 4.11$ & $43.10 \pm 6.90$ & $39.50 \pm 3.90$ & $40.70 \pm 0.90$ \\
MGV (fl) & $74.80 \pm 3.11$ & - & $80.2 \pm 5.90$ & $65.90 \pm 19.10$ & $80.80 \pm 0.80$ \\
MGH (pg) & $25.82 \pm 1.19$ & - & $27.3 \pm 1.60$ & $18.70 \pm 3.50$ & $26.00 \pm 0.20$ \\
MGHC (\%) & $34.54 \pm 2.02$ & - & $34.1 \pm 1.40$ & $29.20 \pm 4.70$ & $32.10 \pm 0.20$ \\
Leukocytes $\left(10^{3} / \mathrm{mm}^{3}\right)$ & $10.40 \pm 4.36$ & $14.17 \pm 1.83$ & $11.22 \pm 4.62$ & $12.80 \pm 5.40$ & $12.1 \pm 0.70$ \\
Basophils $\left(10^{3} / \mathrm{mm}^{3}\right)$ & $0.03 \pm 0.08$ & - & $0.005 \pm 0.02$ & $0(0 \%)$ & $0.00 \pm 0.00$ \\
Basophils $(\%)$ & $0.40 \pm 0.89$ & - & - & - & - \\
Eosinophils $\left(10^{3} / \mathrm{mm}^{3}\right)$ & $1.96 \pm 1.89$ & - & $0.57 \pm 0.53$ & $0.10 \pm 0.10$ & $0.70 \pm 0.10$ \\
Eosinophils $(\%)$ & $16.80 \pm 9.73$ & $6.00 \pm 3.71$ & - & $1.00 \pm 1.50$ & - \\
Band cells $\left(10^{3} / \mathrm{mm}^{3}\right)$ & $0.15 \pm 0.14$ & - & $1.73 \pm 4.92$ & $0.40 \pm 1.90$ & - \\
Band cells $(\%)$ & $2.00 \pm 2.82$ & $3.00 \pm 1.76$ & - & $0.10 \pm 0.20$ & - \\
Segmented neutrophils $\left(10^{3} / \mathrm{mm}^{3}\right)$ & $5.55 \pm 2.13$ & - & $12.22 \pm 14.82$ & $10.00 \pm 5.10$ & $8.60 \pm 0.60$ \\
Segmented neutrophils $(\%)$ & $55.8 \pm 11.49$ & $68.10 \pm 9.93$ & - & $76.50 \pm 7.00$ & - \\
Lymphocytes $\left(10^{3} / \mathrm{mm}^{3}\right)$ & $1.88 \pm 0.53$ & - & $4.38 \pm 6.80$ & $2.20 \pm 1.00$ & $2.20 \pm 0.10$ \\
Lymphocytes $(\%)$ & $20.8 \pm 11.12$ & $21.10 \pm 10.18$ & - & $17.80 \pm 6.20$ & - \\
Monocytes $\left(10^{3} / \mathrm{mm}^{3}\right)$ & $0.62 \pm 0.52$ & - & $0.27 \pm 0.28$ & $0.50 \pm 0.20$ & $0.50 \pm 0.00$ \\
Monocytes $(\%)$ & $5.40 \pm 2.70$ & $1.80 \pm 1.14$ & - & $4.50 \pm 1.80$ & - \\
Platelets $\left(10^{3} / \mathrm{mm}^{3}\right)$ & $252.20 \pm 0.79$ & - & $200.00 \pm 0.00$ & $474.80 \pm 353.10$ & -
\end{tabular}

MGHC = mean globular hemoglobin concentration; MGH = mean globular hemoglobin; MGV = mean globular volume. The numbers represent means followed by standard deviations, with the exception of May-Júnior et al. (2009) whose numbers represent means followed by standard errors of the mean. Dashes denote missing data. 
Table 7. The mean serum/biochemical values of the maned wolves in the current study compared with those of Barbiers \& Bush (1995), Mattos (2003) and May-Júnior et al. (2009)

\begin{tabular}{lcccc}
\hline \multicolumn{1}{c}{ Parameters } & This study & $\begin{array}{c}\text { Barbiers \& } \\
\text { Bush (1995) }\end{array}$ & $\begin{array}{c}\text { Mattos } \\
(2003)\end{array}$ & $\begin{array}{c}\text { May-Júnior } \\
\text { et al. (2009) }\end{array}$ \\
\hline Urea (mg/dL) & $57.60 \pm 12.89$ & - & $70.4 \pm 27.5$ & $61.30 \pm 3.60$ \\
Creatinine (mg/dL) & $1.30 \pm 0.41$ & - & $1.6 \pm 0.4$ & $1.10 \pm 0.00$ \\
ALT (UI/L) & $97.60 \pm 26.37$ & $42.00 \pm 24.00$ & $20.7 \pm 9.1$ & $76.10 \pm 14.50$ \\
AST (UI/L) & $49.60 \pm 28.26$ & $36.00 \pm 13.00$ & $24.0 \pm 26.5$ & $55.40 \pm 5.30$ \\
ALP (UI/L) & $80.88 \pm 86.78$ & $50.00 \pm 43.00$ & - & - \\
GGT (UI/L) & $3.80 \pm 1.09$ & - & - & $3.00 \pm 0.50$ \\
Total protein (g/dL) & $6.18 \pm 1.00$ & $6.40 \pm 0.70$ & - & $7.40 \pm 0.30$ \\
Albumin (g/dL) & $3.13 \pm 0.49$ & $3.10 \pm 0.80$ & - & $2.50 \pm 0.10$ \\
Globulin (g/dL) & $3.05 \pm 0.63$ & - & - & $4.90 \pm 0.20$ \\
Creatine phosphokinase (UI/L) & $178.60 \pm 108.92$ & - & - & $297.40 \pm 36.90$ \\
Total bilirubin (mg/dL) & $0.33 \pm 0.13$ & - & - & $0.30 \pm 0.0$ \\
Direct bilirubin (mg/dL) & $0.11 \pm 0.10$ & - & - & - \\
Indirect bilirubin (mg/dL) & $0.22 \pm 0.17$ & - & - & - \\
Triglycerides (mg/dL) & $26.20 \pm 17.12$ & - & - & $28.20 \pm 5.40$ \\
Glucose (mg/dL) & $131.00 \pm 59.07$ & $121.00 \pm 27.00$ & - & $106.40 \pm 5.00$ \\
Cholesterol (mg/dL) & $260.60 \pm 90.99$ & - & - & - \\
Amylase (UI/L) & $204.36 \pm 154.10$ & - & - & - \\
Lipase (UI/L) & $151.66 \pm 109.18$ & - & - & - \\
Calcium (mg/dL) & $9.04 \pm 1.12$ & $9.70 \pm 0.70$ & - & - \\
Phosphate (mg/dL) & $4.70 \pm 1.48$ & $5.20 \pm 2.00$ & - & $5.10 \pm 0.30$ \\
Magnesium (mg/dL) & $2.33 \pm 1.10$ & - & - & - \\
Sodium (mEq/L) & $126.33 \pm 7.09$ & $146.00 \pm 4.00$ & - & $144.80 \pm 1.30$ \\
Potassium (mEq/L) & $3.93 \pm 0.20$ & $4.80 \pm 0.40$ & - & $4.60 \pm 0.10$ \\
Chloride (mEq/L) & $102.66 \pm 6.65$ & $113.00 \pm 4.00$ & - & $106.50 \pm 1.60$ \\
& & & &
\end{tabular}

ALT = alanine aminotransferase; AST = aspartate aminotransferase; ALP = alkaline phosphatase; GGT = gamma-glutamyl transferase. The numbers represent means followed by standard deviations, with the exception of May-Júnior et al. (2009), whose numbers represent means followed by standard errors of the mean. Dashes denote missing data.

should be cautiously interpreted compared with other values found in the literature. Although abnormalities exist in the results at first glance, certain conditions justify the variation of values across studies. The true causes of these laboratory abnormalities should be investigated after careful evaluation or in cases in which an animal shows clinical symptoms of blood disorders.

\section{CONCLUSIONS}

The ultrasound characteristics of the abdominal and pelvic regions of the maned wolf were similar to canine characteristics previously described in the literature. Although the number of animals evaluated was small, ultrasound differences were noted between wolves and dogs, which allow for the following conclusions:

- The echogenicity between the splenic parenchyma and the left renal cortical region are similar when evaluated at the same depth using the same ultrasound image;

- The prostatic region is difficult to identify and evaluate;

- Testes have reduced echogenicity and rough echotexture and the mediastinal region are slightly echogenic and poorly defined;

- The portal vein has a pronounced sigmoid morphology.

Data analyses on the biometrics and various measurements of abdominal structures revealed strong negative linear correlations between the following variables: modified crown-rump length and the length of the left kidney; modified crown-rump length and the volume of the right kidney; thoracic perimeter and the height of the left adre- nal gland at the cranial pole; and thoracic perimeter and the height of left adrenal gland at the caudal pole. These findings enable researchers to estimate the above renal and adrenal gland measurements given the biometric values of the modified crown-rump length and the thoracic perimeter, respectively.

Acknowledgements.- Thanks to the Brazilian Institute of Environment and Renewable Natural Resources (Instituto Brasileiro do Meio Ambiente e dos Recursos Naturais Renováveis; IBAMA), the Wild Animal Triage Center of the Federal University of Viçosa (Centro de Triagem de Animais Silvestres da Universidade Federal de Viçosa; CETAS/UFV), and the Brazilian Federal Agency for the Support and Evaluation of Graduate Education (Coordenação de Aperfeiçoamento de Pessoal de Nível Superior; CAPES) for supporting the research and to the biologist Mariana Moraes and the veterinarian Ana Carolina Ortegal Almeida.

\section{REFERENCES}

Barbiers R. \& Bush M. 1995. Medical management of maned wolves, p.5266. In: Fletchall N.B., Rodden M. \& Taylor S. (Eds), Husbandry Manual for the Maned Wolf Chrysocyon brachyurus. Smithsonian Institution Press, Washington, DC.

Barthez P.Y., Nyland T.G. \& Feldman E.C. 1995. Ultrasonographic evaluation of the adrenal glands in dogs. J. Am. Vet. Med. Assoc. 207(9):11801183. (Apud Nyland et al. 2004d)

Callegari-Jacques S.M. 2003. Bioestatística: princípios e aplicações. Artmed, Porto Alegre, p.84-93.

Christensen G.C. 1964. The urogenital system and mammary glands, p.741-806. In: Miller M.E., Christensen G.C. \& Evans H.E. (Eds), Anatomy of the Dog. W.B. Saunders Company, Philadelphia.

Couto C.G. 2001. Leucopenia e leucocitose, p.924-930. In: Nelson R.W. \& Couto C.G. (Eds), Medicina Interna de Pequenos Animais. $2^{\underline{a}}$ ed. Guanabara Koogan, Rio de Janeiro. 
D’Anjou M. 2008a. Kidneys and ureters, p.339-364. In: Penninck D. \& D’Anjou M. (Eds), Atlas of Small Animal Ultrasonography. Blackwell Publishing, Ames.

D’Anjou M. 2008b. Liver, p.217-261. In: Penninck D. \& D’Anjou M. (Eds), Atlas of Small Animal Ultrasonography. Blackwell Publishing, Ames.

D’Anjou M. 2008c. Abdominal cavity, lymph nodes, and great vessels, p.445-463. In: Penninck D. \& D’Anjou M. (Eds), Atlas of Small Animal Ultrasonography. Blackwell Publishing, Ames.

Dietz J.M. 1984. Ecology and Social Organization of the Maned Wolf (Chrysocyon brachyurus). Smithsonian Institution Press, Washington, DC. 51p.

Dietz J.M. 1985. Chrysocyon brachyurus. Mamm. Spec. 234:1-4.

Finn-Bodner S.T. 1995. The urinary bladder, p.200-235. In: Cartee R.E. (Ed.), Pratical Veterinary Ultrasound. Williams and Wilkins, Baltimore. (Apud Nyland et al. 2004a)

Fletchall N.B. 1995. Natural history, p.6-9. In: Fletchall N.B., Rodden M. \& Taylor S. (Eds), Husbandry Manual for the Maned Wolf Chrysocyon brachyurus. John Ball Zoo, Grand Rapids.

Geisse A.L., Lowry J.E., Schaeffer D.J. \& Smith C.W. 1997. Sonographic evaluation of urinary bladder wall thickness in normal dogs. Vet. Rad. Ultr. 38:132-137.

Graham J. 2008. Adrenal glands, p.385-388. In: Penninck D. \& D’Anjou M.A. (Eds), Atlas of Small Animal Ultrasonography. Blackwell Publishing, Ames.

Hetch S. 2008a. Female reproductive tract, p.397-416. In: Penninck D. \& D'Anjou M.A. (Eds), Atlas of Small Animal Ultrasonography. Blackwell Publishing, Ames.

Hetch S. 2008b. Spleen, p.263-280. In: Penninck D. \& D’Anjou M.A. (Eds), Atlas of Small Animal Ultrasonography. Blackwell Publishing, Ames.

IBAMA 2003. Lista de Espécies da Fauna Brasileira Ameaçadas de Extinção. Brasília. 31p.

Kamikawa L. \& Bombonato P.P. 2007. Ultrassonografia da aorta abdominal e de seus ramos em cães. Ciência Rural 37:412-417.

Kealy J.K. \& McAllister H. 2005. O abdome, p.19-148. In: Ibid. (Eds), Radiologia e Ultrassonografia do Cão e do Gato. $3^{\text {a }}$ ed. Manole, São Paulo.

Larson M.M. 2009. The kidneys and ureters, p.185-204. In: O’Brien R. \& Barr F. (Eds), BSAVA Manual of Canine and Feline Abdominal Imaging. British Small Animal Veterinary Association, Gloucester.

Maia O.B. \& Gouveia A.M.G. 2002. Birth and mortality of maned wolves Chrysocyon brachyurus (Illiger, 1811) in captivity. Braz. J. Biol. 62(1):2532.

Mattoon J.S. \& Nyland T.G. 2004. Próstata e testículos, p.255-269. In: Ibid. (Eds), Ultrassom Diagnóstico em Pequenos Animais. 2 ${ }^{\underline{a}}$ ed. Roca, São Paulo.

Mattos P.S.R.D. 2003. Epidemiologia e genética populacional do lobo-guará, Chrysocyon brachyurus (Illiger, 1915) (Carnívora, Canidae) na região nordeste do Estado de São Paulo. Tese de Doutorado em Ciências Biológicas, Universidade Federal de São Carlos, São Carlos, SP. 98p.

May-Júnior J.A., Songsasen N., Azevedo F.C., Santos J.P., Paula R.C., Rodrigues F.H.G., Rodden M.D., Wildt D.E. \& Morato R.G. 2009. Hematology and blood chemistry parameters differ in free-ranging maned wolves (Chrysocyon brachyurus) living in the Serra da Canastra National Park versus adjacent farmlands, Brazil. J. Wildl. Dis. 45(1):81-90.

Nyland T.G., Matoon J.S., Herrgesell E.J. \& Wisner E.R. 2004a. Trato urinário, p.161-198. In: Nyland T.G. \& Mattoon J.S. (Eds), Ultrassom Diagnóstico em Pequenos Animais. 2a ed. Roca, São Paulo.

Nyland T.G., Matoon J.S., Herrgesell E.J. \& Wisner E.R. 2004b. Fígado, p.95130. In: Nyland T.G. \& Mattoon J.S. (Eds), Ultrassom Diagnóstico em Pequenos Animais. 2 $2^{\underline{a}}$ ed. Roca, São Paulo.

Nyland T.G., Matoon J.S., Herrgesell E.J. \& Wisner E.R. 2004c. Pâncreas, p.147-160. In: Nyland T.G. \& Mattoon J.S. (Eds), Ultrassom Diagnóstico em Pequenos Animais. $2^{2}$ ed. Roca, São Paulo.

Nyland T.G., Matoon J.S., Herrgesell E.J. \& Wisner E.R. 2004d. Glândulas adrenais, p.199-210. In: Nyland T.G. \& Mattoon J.S. (Eds), Ultrassom Diagnóstico em Pequenos Animais. 2ª ed. Roca, São Paulo.

Peixoto G.V., Hage M.C.F.N.S., Paula T.A.R., Alvarenga F.M., Carretta Júnior M., Costa P.R.S., Carneiro F.T. \& Silva L.C. 2009. Sliding esophageal hiatal hernia in maned wolf (Chrysocyon brachyurus, Illiger, 1815). Annals 15th Congress of the International Veterinary Radiology Association, Búzios, RJ, Vol.1, p.130. (Resumo)

Penninck D. 2004. Trato gastrintestinal, p.211-234. In: Nyland T.G. \& Mattoon J.S. (Eds), Ultrassom Diagnóstico em Pequenos Animais. $2^{\underline{a}}$ ed. Roca, São Paulo.

Penninck D. 2008. Gastrointestinal tract, p.281-318. In: Penninck D. \& D'Anjou M.A. (Eds), Atlas of Small Animal Ultrasonography. Blackwell Publishing, Ames.

Penninck D., Nyland T.G., Fisher P.E. \& Kerr L.Y. 1989. Ultrasonography of the normal canine gastrointestinal tract [Abstract]. Vet. Rad. 30:272276.

Pessutti C. \& Santiago M.E.B. 1994. Protocolo de manejo para o lobo-guará (Chrysocyon brachyurus) e resposta ao segundo questionário biológico, veterinário e ambiental. Sociedade de Zoológicos do Brasil, Sorocaba.

Santos S.E.C., Garcia J.F., Vannucchi C.I., Maldonado A.L.L. \& Santos F.A.M. 2004. Ultrasonographic dimensions of normal Great Dane male dogs sex organs. Comunicação breve. Revta Port. Ciênc. Vet. 99:123-124.

Sartor R. 2008. Dopplerfluxometria e avaliação morfométrica da veia porta em cães hígidos de diferentes pesos corpóreos. Dissertação de Mestrado em Medicina Veterinária, Universidade Estadual Paulista "Júlio de Mesquita Filho", Botucatu, SP. 98p.

Vac M.H. 2004. Sistema urinário: rins, ureteres, bexiga urinária e uretra, p.111-144. In: Carvalho C.F. (Ed.), Ultrassonografia em Pequenos Animais. Roca, São Paulo. 